\title{
A dimensão cognitiva da linguagem: um sucinto panorama
}

Letícia M. Sicuro Corrêa

É com prazer que apresento o presente volume, produto da iniciativa de alunos do Programa de Pós-Graduação Estudos da Linguagem da PUC-Rio e da participação de estudantes de pós-graduação em diferentes pontos do país.

Ao tematizar a língua (gem) em sua dimensão cognitiva, a Revista Escrita abre-se a um dos campos de investigação que mais tem atraído pesquisadores com interesse em desvendar a natureza humana, desde meados do século XX, quando a naturalidade do processo de aquisição da linguagem foi problematizada na teoria linguística e processos linguísticos passaram a ser abordados sob a ótica do processamento de informação. No Brasil, a pesquisa linguística de viés cognitivo, na qual se inclui a investigação psicolinguística, vem despertando a curiosidade de um número crescente de jovens que, partindo de uma formação em Letras/Linguística, buscam ultrapassar fronteiras entre disciplinas no tratamento de questões pertinentes à aquisição e ao processamento da linguagem, no campo mais amplo das ciências cognitivas.

O conjunto diversificado de artigos do presente volume aponta para um amplo espectro de questões relevantes para o entendimento da natureza cognitiva da linguagem, desde o processamento do sinal da fala por bebês, no processo de aquisição da língua materna, a habilidades metacognitivas voltadas para a produção da escrita. Esse conjunto de artigos ilustra ainda possíveis abordagens que vêm sendo exploradas no tratamento das diferentes questões, as quais se complementam em direção ao entendimento do que a faculdade de linguagem pode propiciar e do que o uso da língua pode requerer.

Tomando a língua materna como objeto de conhecimento, com foco nos itens funcionais, o primeiro artigo deste volume (Artigo 1) busca clarificar de que modo o processamento do material linguístico percebido pela criança pode possibilitar a segmentação de elementos a serem relacionados de forma hierárquicas assim como a identificação do que é específico da gramática uma dada língua. Um aspecto específico da gramática do Português Brasileiro (PB), por exemplo, é aqui tematizado - os chamados nomes nus (Artigo 2). Estes apresentam-se como uma das opções para a formulação da referência genérica facultada a línguas humanas, a qual pode ser, não obstante, custosa para o processamento linguístico em determinadas condições.

A relação demandas específicas da produção da linguagem e o modo como recursos gramaticais são postos em uso é um dos pontos que sobressaem nos artigos aqui coletados. Observa-se, por exemplo, que o processamento da correferência intersentencial (Artigo 4) requer que a concatenação de enunciados no discurso flua na fala/escrita de forma a possibilitar a integração de informação pelo ouvinte/leitor. Fatores cognitivos independentes da língua em questão impõem, então, restrições às opções gramaticais que se tornam acessíveis na retomada de um antecedente. Nem sempre, contudo, o que se mostra menos custoso do ponto de vista de quem fala ou escreve revela-se o mais adequado do ponto de vista do ouvinte/leitor. O automonitoramento da produção da fala/escrita (Artigo 6), no qual os papéis de produtor e de ouvinte/leitor são intercambiados quase simultaneamente, vem em direção da 
sintonia entre interlocutores, crucial para que o custo de processamento seja minimizado em língua oral ou escrita e a interlocução seja efetiva.

Condições particulares de produção da fala apresentam, não obstante, demandas específicas, como revelam os "erros de precisão na fluência" detectados na leitura oral (Artigo 3). Uma vez que leitura oral envolve o reconhecimento de palavras a partir do sinal gráfico, a análise sintática dos enunciados que se apresentam por escrito, a imposição de uma prosódia a estes e sua eventual compreensão, precedendo ou transcorrendo em paralelo à reprodução daqueles de forma articulada, constata-se que as demandas para que a fluência seja atingida são consideráveis. Os "erros" em questão podem, assim, apontar para aspectos do processo de leitura cujo desenvolvimento encontra-se em processo, e que, sendo particularmente vulneráveis ao efeito de fatores sociais, podem requerer uma intervenção direcionada, da parte de educadores.

De forma análoga, o monitoramento da produção da linguagem, quando estendido à revisão da escrita por crianças (Artigo 5), mostra-se instrumental para o entendimento das demandas cognitivas específicas da produção da escrita. O quanto a consciência fonológica e a consciência morfológica favorecidas pela aquisição de habilidades de leitura e escrita contribuem para o desenvolvimento dessas habilidades é uma questão, cujo tratamento pode ser facilitado com o uso de testes específicos para esse fim (Artigo 7).

Enfim, os artigos apresentados no presente volume fazem um sucinto panorama de questões relevantes no tratamento da linguagem em sua dimensão cognitiva e apontam para o potencial de aplicabilidade de teorias do processamento linguístico. Tais questões se multiplicam, não obstante, quando a interface da língua interna com os sistemas perceptuais se faz por meio de recursos gestuais/faciais-visuais (Artigo 8). As línguas de sinais, como línguas naturais da população surda, demonstram que a faculdade de linguagem encontra diferentes meios de se materializar para que a natureza humana se manifeste plenamente.

Que os trabalhos aqui apresentados estimulem a busca por um melhor entendimento das potencialidades e realizações da cognição humana. E que, apoiadas no conhecimento acerca da aquisição e do processamento da linguagem, ações sociais efetivas possam ser conduzidas nas condições externas do desenvolvimento linguístico, de forma a garantir que as potencialidades humanas se realizem da melhor forma em todo o indivíduo. 